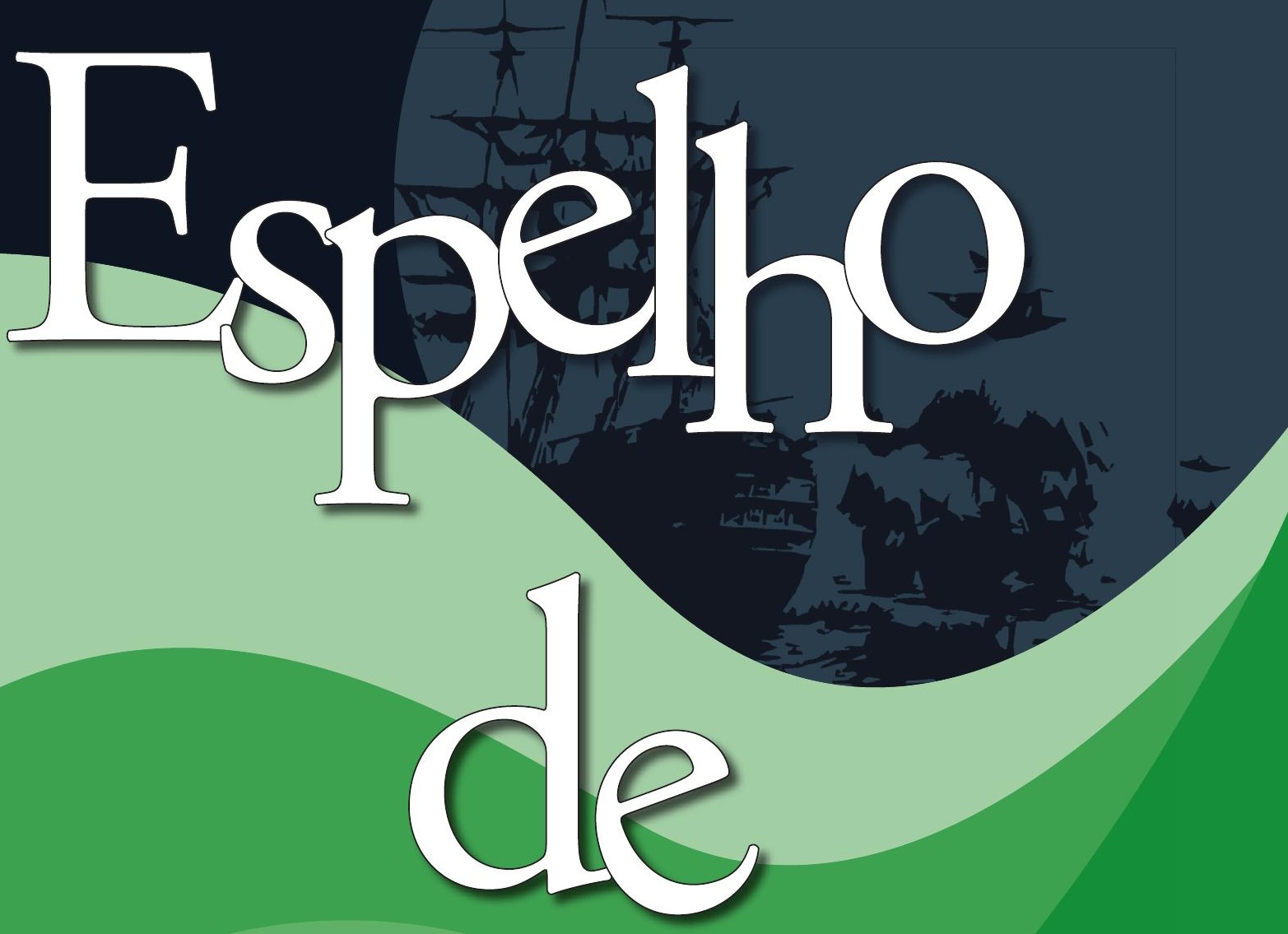

0

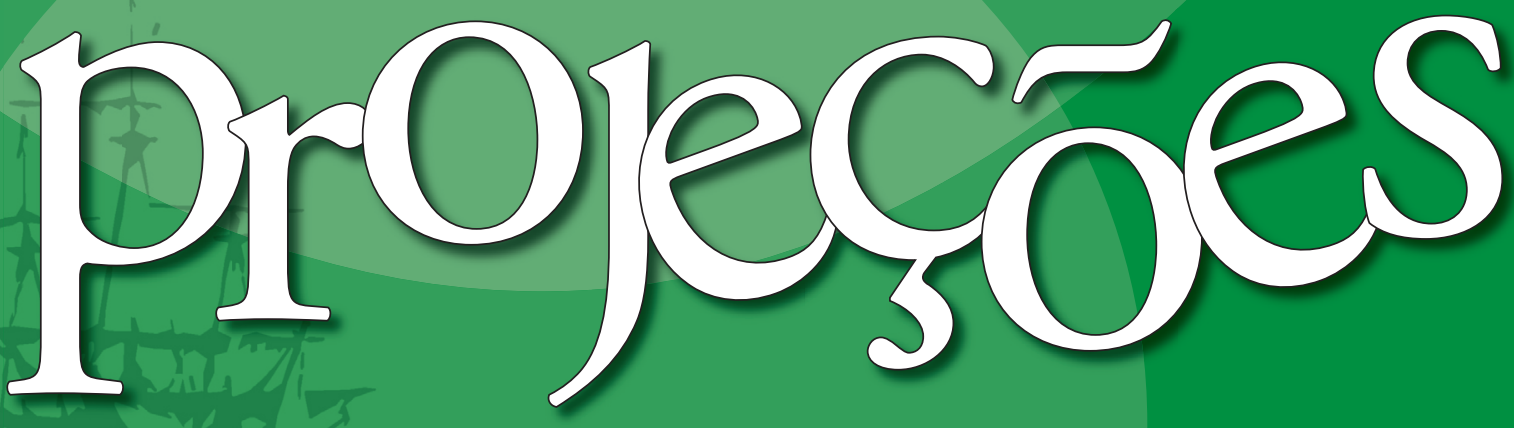




\title{
Os franceses no Brasil de D. João
}

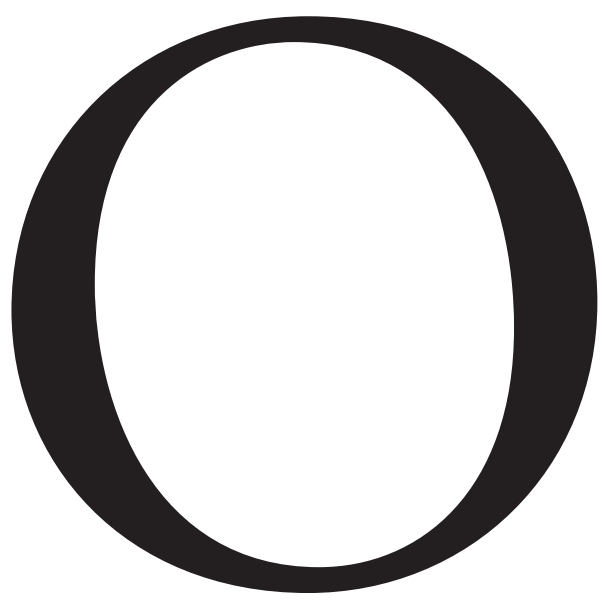

\author{
LILIA MORITZ SCHWARCZ
}

ano de 1808 marca o começo de um novo período para a colônia luso-americana e para as relações que passaria a travar com os países europeus. Pressionado pelas duas maiores potências européias - Inglaterra e França -, o príncipe regente, não sem grandes hesitações, opta pelo lado inglês, que significava à primeira vista uma garantia de chegada segura ao Brasil. Mas significou mais: uma espécie de bloqueio aos franceses, sobretudo, nesses trópicos lusitanos. Assim, se o primeiro decreto promulgado na

LILIA MORITZ SCHWARCZ é professora do Departamento de Antropologia da FFLCH-USP e autora de, entre outros, 0 Espetáculo das Raças (Companhia das Letras).
Bahia - em 28 de janeiro de 1808 - assegurava a "abertura dos portos às nações amigas", e o de 25 de janeiro de 1809 dava aos estrangeiros o direito de receber sesmarias, nas mesmas condições que os portugueses, já a França seria excluída desses primeiros acordos e tratada, desde então, como inimiga. Em terras brasileiras o regente declararia guerra à França - em primeiro de maio de 1808 -, assim como seu exército invadiria a Guiana Francesa, em 3 de dezembro. Brasil e França não manteriam mais relações diplomáticas ou comerciais até a assinatura da paz em 1814, na esteira das demais determinações do Congresso de Viena.

O primeiro tratado - assinado em 30 de maio de 1814 - previa a reparação das Guianas, além de versar sobre demais pendências deixadas de parte a parte. Além do mais, a 18 de junho do mesmo ano, D. João mandava publicar que as relações entre os países eram "amigáveis", o que implicava franquear o livre trânsito de franceses em Portugal, mas também no Brasil. O ministro Antônio de Araújo de Azevedo, o conde 
da Barca, durante todo esse período, e mesmo antes dele, foi sem dúvida o político mais empenhado na manutenção das boas relações com a França e, se havia sido colocado um pouco de escanteio, devido à "saída inglesa", logo após a morte do conde de Linhares, em 1812, e com o reatamento entre os dois países, passou a atuar fortemente no sentido de obter um clima mais favorável aos franceses, até então proibidos de entrar no território. Trabalhou para que novo decreto, datado de 18 de novembro, abrisse finalmente os portos do Brasil aos navios comerciais franceses. Por fim, em dezembro do mesmo ano, o coronel JeanBaptiste Maler foi nomeado cônsul-geral da França no Brasil, chegando ao Rio de Janeiro em abril de 1815. Data desse momento, pois, o começo das novas relações oficiais franco-brasileiras, assim como se aceleram as trocas culturais, econômicas, científicas e comerciais entre as duas nações.

Mas projeções existiam de parte a parte. Se os portugueses entendiam a França como o berço da "cultura" e da civilização, já os franceses, cuja curiosidade ficara por tanto tempo represada, viam no Brasil a utopia da terra edênica, da terra sem males e do eldorado possível. E assim a colônia seria vista a partir de um novo jogo de espelhos, em que se contrastava a vasta e imaginosa representação (feita de relatos de viajantes de séculos passados), com a nova realidade dos viajantes etnógrafos, que agora carregavam seu depoimento testemunhal. E os interesses e disposições seriam muitos: se algumas missões buscavam as vantagens econômicas até então bastante controladas pelos ingleses ${ }^{1}$, chegariam, também, outras, que desbravavam o território, imbuídas por um "sentimento de natureza". Afinal, o Brasil era para esses novos viajantes um país conhecido e desconhecido. Era, por um lado, um "velho amigo", uma vez que, através dos relatos coletados durante três séculos - a partir das obras de Thévet, Lery, Goneville, Claude d'Abeville, Duguay Trouin, Bouganville e tantos outros -, o Brasil surgia como o local da grande flora e da fauna diversificada. No entanto, a colônia parecia, também, um continente misterioso, com suas gentes de costumes estranhos. Os franceses pareciam querer, portanto, redescobrir um país conhecido há muito tempo, e o desejo reprimido por tantos anos era agora transformado em realidade. Paradoxalmente, essa era a mais "exótica" e a mais "civilizada" das colônias americanas: uma monarquia cercada de repúblicas por todos os lados. A colônia portuguesa era, assim, um imenso desafio a resumir e reunir as riquezas e imaginários dispersos por toda a América.

Marcados por esse espírito ambivalente entraram cientistas como Saint-Hilaire, artistas acadêmicos daquela que ficou conhecida como a "Missão Francesa" - que contava com Jean-Baptiste Debret, Nicolas Antoine Taunay, Grandjean de Montigny e tantos outros-, ou cronistas como Ferdinand Denis, que se deixariam contaminar, mas, também, alterariam, e muito, a paisagem local.

\section{RUMO AO BRASIL}

Seja nas versões mais positivas, seja nas evidentemente negativas, esse Novo Mundo sempre foi lugar da dubiedade: da semelhança e da dessemelhança. Semelhança na sua prosperidade, na sua humanidade leal, na sua natureza infinda e nos sonhos de igualdade que permitia adivinhar. Dessemelhança diante dessa terra de nomes, produtos e gentes diversas: por vezes aprazíveis, por vezes não. E é em meio a esse mar de sensações que em 1816 dezessete navios partem do porto de Havre com destino ao Brasil. Gendrin, um jovem comerciante especializado em tapetes que embarcara no barco Antígone, avaliou que a presença da corte do Brasil é que teria atraído "capitalistas e artesãos de arte, que a crise da indústria francesa deixara sem emprego". Completa o comerciante: "A maioria tencionava exercer no Brasil a profissão de joalheiro, fabricante de armas ou de selas; alguns se destinavam à profissão de alfaiate; outros enfim, que não tinham aprendido profissão alguma, contavam com a sorte para fazer fortuna"2. "Fazer fortuna" 
- e "a América" - era a palavra de ordem, sobretudo diante de uma França devastada pela guerra e sem grandes perspectivas. Para antigos bonapartistas, perseguidos a partir de então, a saída se apresentava como uma possibilidade real. Para os mais aventureiros, essa "terra sem males" era promessa de boa fortuna. Por outro lado, por mais estranho que possa parecer, a presença de uma monarquia parecia significar a garantia de um governo sem maiores conturbações. Nada mais paradoxal para esses filhos da Revolução e da República, mas que ainda viam a realeza como símbolo de estabilidade. O próprio Gendrin vinha começar um negócio com seu patrão no Rio de Janeiro e tinha a intenção de permanecer na corte até 1821 , quando resolve morar no Chile, e retorna à França em 1823. Os caminhos eram incertos e as oportunidades também, e era melhor agarrá-las quando e onde se apresentassem. E, dentre aqueles que chegavam ao Brasil, havia de tudo. Profissionais, curiosos, cientistas, literatos, religiosos, comerciantes, jovens e velhos.

Entre os jovens estava, por exemplo, Ferdinand Denis, que deixou Havre em 24 de agosto de 1816. Tinha 18 anos e queria formar um patrimônio para sua irmã: "Eu vou arrancar da terra do Brasil um dote para a gentil Cisca, e um bem-estar para todos vocês"3. Mais uma vez, no imaginário produzido ainda no Velho Mundo, a colônia intocada dos portugueses surgia como caminho certeiro para a formação de bom pecúlio. A família de Denis fazia parte da burguesialiberal francesa, mas perdera muito da sua estabilidade financeira por causa da situação política local. Seu pai e seu irmão haviam sido destituídos de seus postos após a Restauração, fato que motivou Ferdinand a partir para o Brasil: passaria os primeiros seis meses no Rio de Janeiro e os dois anos seguintes na Bahia. Pensava seguir a carreira diplomática, mas, já no país, começou a ter outros planos que incluíram a agricultura e depois a indústria. Denis retornaria à França no final de 1819; voltava ao Velho Mundo levando uma visão "maravilhada" desse Brasil: uma espécie de revelação da juventude, uma grande paixão da vida toda.
Na colônia portuguesa também faria novos amigos franceses, como o escritor Tollenare, a quem conheceu na Bahia. Denis escreveria um livro sobre o país, junto com Hippolyte, um dos cinco filhos do pintor Nicolas-Antoine Taunay, Resume de l'Histoire du Brésil, publicado em 1825. Em seu prefácio comentaria: "Eu conheci esse país numa época em que ele ainda andava longe de propiciar esperanças tão brilhantes [...]. Pela sua fertilidade e pelas suas riquezas naturais, o Brasil pode ocupar o primeiro lugar na América Meridional [...]. Esse país que parece chamado para tão altos destinos" $"$. Como se pode notar, as expectativas eram grandes e o Brasil representava uma jovem, promissora e pouco explorada nação. Na abertura do livro de Denis consta a referência a outra obra dele, Cenas da Natureza sobre os Trópicos e Sua Influência na Poesia, cuja epígrafe é de Humboldt e assim diz: "Nós não duvidamos que o clima, a configuração do solo, a aparência dos vegetais, o aspecto de uma natureza risonha ou selvagem influenciem no progresso das artes e o estilo que distingue as suas produções". Eram os trópicos a penetrar a imaginação de nossos viajantes franceses, que ficavam ou voltavam contaminados pelos ares do Brasil ${ }^{5}$.

Mas junto com os comerciantes, artesãos e jovens de espírito aventureiro chegou ao Brasil, também, um bom número de bonapartistas, constrangidos a emigrar por conta das proscrições estabelecidas entre julho de 1815 e janeiro de 1816 . Tollenare fez alusões a esses imigrantes, que agora preferiam utilizar o nome genérico de "jacobinos"6. Essa era a época do “Terror Branco" e antigos simpatizantes de Napoleão passavam a esconder antigas paixões, que muitas vezes haviam custado a perda do emprego, da situação social e da fortuna. E é por isso que a viagem romântica era, nesse caso, remédio, mas também veneno. Remédio, pois redimia, como dizia Chateaubriand, a nostalgia de época; veneno na medida em que levava a alterações radicais.

E no meio desse grupo encontrava-se uma colônia de artistas, contaminada por esses depoimentos, tão reais quanto imagi-

\footnotetext{
3 Ferdinand Denis, "Lettre de Bahia, 9 juin 1817", in Potelet, op. cit., p. 25.

4 Idem, Résumé de l'Histoire du Brésil, Paris, Lecointe et Durey Libraires, 1825

5 Idem, Scènes de la Nature sous les Tropique et de Leur Influence Sur la Poésie, Paris, Imprimerie de Lachevardiere Fils, s.d.

6 Ver Potelet, op. cit., p. 29
} 
nários. Na França consumia-se largamente esse tipo de literatura de viagem, e como boa parte desses artistas provinha de ambientes letrados devem ter se deparado ou com relatos de primeira mão, ou ao menos com compêndios como os de Prévost e Beauchamp, que cantavam louvores a essa nova paisagem. Um reino promissor é oque surgia dessas páginas; uma terra em que tudo era possível, uma nova vida até.

O viajante Jacques Arago assim definiu o lugar: "Aqui está o Brasil, terra talvez das mais fecundas da Terra; nós diríamos uma natureza à parte, uma natureza privilegiada. Para se enriquecer, a cobiça precisa apenas cavocar o solo, para viver o homem não precisa mais do que respirar $[\ldots]$ "7. As duas primeiras páginas de Souvenirs d'un Aveugle de Jacques Arago mereceriam ser citadas na íntegra tal o caráter sintético da narrativa. Lá estão os lugares-comuns, as mesmas identificações, os empregos laudatórios dos termos sempre evocados quando se falava do Brasil. Suas riquezas não teriam paralelo, sua natureza seria infinda, seu clima, o mais agradável, seu mar, delicioso. Mesmo o Oriente fabuloso, que durante tanto tempo fez a Europa sonhar, parecia não ter comparação com essa América redescoberta pelos franceses: “Aqui as montanhas abrigam pedras preciosas, os riachos pepitas de ouro e diamantes tão belos como aqueles de Golconda"8. Comparado às ruínas misteriosas e imensas de Golconda, na Índia, o Brasil parecia ser o Oriente das Índias Ocidentais. Havia uma evidente associação de idéias e a transferência era das mais imediatas: duas maravilhas, dois exotismos - o oriental e o americano - se confundiam. Mas a persistência do maravilhoso brasileiro estava muito conectada à ignorância da realidade física, econômica e humana do país. Diferente das colônias espanholas, das quais já havia algum conhecimento científico acumulado, o Brasil permanecia como uma lacuna e chamava pela aventura, pela curiosidade científica e pelo desejo de fazer fortuna. As primeiras obras que aparecem a partir de 1815 representam, pois, uma tentativa de animar todo tipo de comércio entre os dois países. Os novos livros se apresentam como "novidade recente", mas não passam, na maioria das vezes, de coleções de generalidades, espécie de anedotas acumuladas e retiradas dos diferentes relatos.

Destaca-se nesse sentido a obra de Beauchamp, um modelo de lirismo panegírico: "Esse possante império tão magnífico, vai logo se equilibrar com a força crescente dos Estados Unidos"9. Nada mais adequado para viajantes que se preparavam para cruzar o Oceano e sonhavam com maravilhas sem-fim. Beauchamp, um historiador de divulgação, escreveu uma coleção sobre a história do Brasil em 12 pequenos volumes. Publicados em 1815, exatamente no momento da abertura de relações, os títulos representaram a primeira obra geral sobre o país em língua francesa. Beauchamp enaltece a oportunidade da chegada do príncipe regente ao Rio de Janeiro, saúda os melhoramentos realizados e termina exaltando:

"A transmigração da potência portuguesa dá ao Império Braziliense as mais brilhantes esperanças; este Império parece ser chamado para gozar agora dos mais altos destinos. Quem poderá calcular de antemão onde parará a energia de uma nação, por assim dizer ressuscitada? [...] Este Império, tão poderoso como magnífico, balanceará dentro em pouco o poder desmedido dos Estados Unidos e terá por si a vantagem de um clima aprazível, de um terreno fértil em produções úteis e preciosas, e de uma posição geográfica, dominando o caminho das duas Índias e de todos os mares do Globo formando como o nó das comunicações comerciais de todas as partes do mundo civilizado. Quanto é mais forte e inexpugnável este Império do Hemisfério Austral! Quanto é nobre, e independente, o seu destino!"10.

A vinda da família real é compreendida, pois, como uma medida quase "natural"; assim como natural parece ser a história para Beauchamp. O fato é que o Brasil ganhava, na França, uma história com começo, meio e fim, e nada mais prático para 
Mas talvez o autor mais importante para a vinda de tantos franceses e, sobretudo, da colônia de artistas chefiados pelo poderoso secretário da Classe de Belas-Artes do Instituto de França, Joaquim Lebreton, tenha sido não um francês, mas o viajante alemão Alexandre von Humboldt, que percorreu toda a América espanhola e, em 1811, teve seu livro Essai Politique sur le Royaume de La Nouvelle-Espagne traduzido para o francês. Humboldt era membro do Institut de France e colega fraterno de Lebreton. Sabia, pois, que o amigo andava com problemas políticos desde que se negara a devolver as peças artísticas conquistadas na época do Império de Napoleão ${ }^{11}$. A obra começava com novo prefácio, em que o cientista viajante declarava ser a América a mais "bela porção do globo"12. O livro descreve a localização dos vários países do continente, mas é a situação do México que chama a atenção de Humboldt. Segundo ele, na cidade do México se observaria um grande movimento intelectual e a presença de uma "juventude com rara facilidade para aprender os princípios da ciência”. Exulta, ainda, ao confirmar que "nenhuma cidade do Novo Continente, sem a exceção dos Estados Unidos, ofereceria estabelecimentos científicos tão grandes e sólidos como a capital do México" e menciona, por fim, a Academia de Pintura e Escultura. E é nesse ponto que a narrativa de Humboldt deve ter interessado aos pintores e viajantes. A descrição de Humboldt vai num crescente:

se vê, a monarquia andava novamente em alta, e os Braganças eram entendidos como reis irmanados aos soberanos franceses. Famílias e parentelas compunham laços de sangue e de "civilidade", e a corte tropical parecia, agora, um porto seguro. Beauchamp resumia, sem saber, os sonhos de nossos artistas, artesãos, viajantes, cientistas ou comerciantes, que pretendiam ajudar a construir este país, introduzindo as luzes, o progresso, "a cultura" e (por que não) as belas-artes no Brasil. Escravos quase não existiam nesses relatos, assim como os nativos pareciam todos "domesticados". Também sumiram os insetos, as serpentes e as bestas dos primeiros relatos; em seu lugar reinava a natureza edênica do Brasil.
"Essa academia leva o título de Academia de las Nobles Artes de México [...]. O governo designou um lugar espaçoso, no qual se encontra uma coleção de gessos, os mais belos e os mais completos que se pode encontrar em qualquer parte da Alemanha [...]. É no edifício da Academia [...] que se reúnem as esculturas mexicanas; as estátuas cheias de hieróglifos e que oferecem paralelos com o estilo egípcio ou hindu. É curioso visitar monumentos da primeira cultura de nossa espécie, as obras de um povo semi-bárbaro que habita os Andes mexicanos, ao lado das belas formas que foram nascidas ao céu da Grécia e da Itália"13.
11 Para uma visão mais ampla do incidente ver: Lilia Moritz Schwarcz, OSol do Brasil, São Paulo, Companhia das Letras, 2008

12 Alexandre von Humboldt, Essai Politique sur le Royaume de La Nouvelle-Espagne Paris Chez F. Schoell, 1811, pp. 1-2.

13 Idem, ibidem, pp. $118-9$. 
Humboldt demonstra compactuar com valores dos naturalistas da época, que reconhecem a importância de outras culturas, mas sempre as definem como "bárbaras" ou inferiores às suas. No entanto, emociona-se com o paralelo entre elas e as "verdadeiras civilizações": as gregas ou romanas. O autor continua definindo os custos da Academia mexicana e mostrando como o governo, mas também os negociantes da capital arcam com as despesas. Segundo Humboldt, seria grande a influência que a instituição deveria exercer "no gosto da nação”. Quase emocionado, descreve uma reunião que presenciou: "Nessas reuniões [...], as cores, as raças de homens se confundem $[\ldots]$. É consolador observar que, sob todas essas zonas, a cultura das ciências e das artes estabelece uma certa igualdade entre os homens, fazendo-os esquecer suas pequenas paixões em nome da felicidade social" 14 . Humboldt, como bom humanista e defensor da igualdade, ficara encantado com o que vira: naAcademia mexicana teria encontrado um recinto onde conviveriam várias civilizações e onde "a ciência reinaria acima das demais divisões humanas".

Aobra de Humboldt inflamou ainda mais a imaginação dos franceses, assim como seria apreciada por muitos daqueles que se dirigiam ao Brasil. Maria Graham, por exemplo, que por aqui esteve entre 1821 e 1823 , teria afirmado que a fim de entender esse país pouco conhecido teria lido Humboldt e seus relatos sobre a América do Sul, assim como os escritos de Robert Southey, History of Brazil ${ }^{15}$.

A América espanhola já era conhecida,

14 ldem, ibidem, p. 120.

15 Ver Maria Graham, Journal of a Voyage to Brazil, London, Printed for Longman, Hurst Ress, Orme, Brown, and Green, and. Murray, Albermarle-street 824; e Elizabeth Mavor led. The Captain's Wife, London, Weidenfeld and Nicolson, 1993

16 Franz Bôas, Antropologia Cultural, Rio de Janeiro, Zahar 2004

17 Sugerimos a leitura, entre outros, de: Lilia Moritz Schwarcz, A Longa Viagem da Bibliotecados Reis, São Paulo, Companhia das Letras, 2002. mas a portuguesa continuava, na concepção da maioria, praticamente "virgem" e carregava potencial semelhante: grandes civilizações, uma bela natureza, a convivência saudável entre os grupos sociais, e (assim pensavam) comerciantes abonados. De toda maneira, o relato dos viajantes seria revisto não mais como miragem: agora, esse imenso desconhecido chamado Brasil estava disposto bem à frente dos olhos. Mas nem todos vêem com olhos livres, e como disse o antropólogo Franz Bôas: "o olho que vê é órgão da tradição"16. Os artistas franceses tentarão deslocarexperiências e rearranjá-las dentro de seus esquemas interpretativos e das convenções que possuíam. Por essas e por outras é que o Brasil transformava-se num grande jogo de espelhos: um país imaginado, sonhado, desejado e pensado por uma série de homens que usaram suas lentes corretoras para descrever essa realidade que sempre foi, por suposto e de partida, maravilhosa. Do outro lado do espelho, estava a escravidão, que se espalhava por todo o território, e a realidade dessa corte estacionada em seu paraíso tropical. Muitas convenções levavam a uma difícil tradução.

\section{A COLONNIA LEBRETON: A AMÉRICA COMO UMA NOVA ROMA}

Só em 1815 que a colônia seria elevada à condição de Reino Unido, num claro sinal de que o regente, a despeito das viradas na política internacional e da queda de Napoleão, não pretendia retornar para a metrópole. Além do mais, uma série de melhorias havia sido introduzida no Rio de Janeiro, assim como toda a pesada estrutura administrativa lusitana fora deslocada para o Brasil, de maneira que o local agora, de fato, parecia como a nova sede do império ${ }^{17}$. Por isso mesmo, seria até "natural" prever a vinda de especialistas, contratados para representar essa exótica corte tropical. No entanto, é hora de olhar essa história por outro lado e estranhar.

A corte tinha lá seus interesses na chegada de um grupo de artistas acadêmicos, que poderia reformular e elevar sua representação oficial, sobretudo nesse momento delicado em que a realeza se encontrava. Diante do Velho Mundo, e pensando nas demais monarquias que também começavam a levantar-se após a queda de Napoleão, era preciso divulgar imagens que destacassem a singularidade dessa realeza lusitana, que geria seus negócios aquartelada em sua longínqua colônia tropical. Por outro lado, 
o Império português era imenso e, apesar de a essas alturas o eixo econômico concentrar-se no Atlântico Sul, possessões na África ou mesmo na Ásia andavam carentes não só de notícias, mas de imagens dessa nova administração colonial. Além do mais, também em Portugal contestava-se cada vez mais a atitude do príncipe, que, apesar dos ânimos serenados após os Tratados de Paz de 1815, não dava sinais de querer deixar sua vida na América. Por fim, nessa sociedade majoritariamente iletrada, uma iconografia oficial bem que ajudaria na conformação de uma simbologia pátria. Motivos aparentes não faltavam e assim amadureceria na historiografia a idéia da formação de uma verdadeira "missão" que traria nova representação para uma corte imigrada, ainda temerosa e bastante isolada. Segundo essa versão, os artistas contratados tratariam de mostrar como aí estava uma realeza tão tradicional como as demais e cujo passado engrandecido por alegorias da Antigüidade seria devidamente enaltecido e se espelharia no presente.

Para tanto, seria no mínimo adequado ter à disposição artistas acostumados a lidar com as necessidades do Estado. Ejustamente um grupo de pintores e escultores neoclássicos franceses - nesse momento isolados politicamente - viria bem a calhar. É certo que esses estavam habituados a consagrar a glória do antigo imperador Napoleão. No entanto, estavam acostumados, também, com o poder e suas guinadas e bem que seriam úteis na tarefa de engrandecimento dessa corte. Aliás, essa era uma prática corrente durante o Antigo Regime: os reis costumavam contratar "artistas mercenários" habituados à glorificação do poder. E nesse caso não seria diferente: assim como haviam dado um caráter sacro ao Império de Napoleão, cuidado dos monumentos, das festas, das moedas, e produzido imensas telas, o mesmo seria possível realizar nessa nova capital provisória do Império português. Por outro lado, nada melhor do que aproveitar o "espólio do império napoleônico", alguns pintores que cumpriam também o papel de agentes de propaganda do antigo Estado francês.
E assim, juntando seis com meia dúzia, conta a história que, em 1815, D. Pedro José Joaquim Vito de Menezes Coutinho, o marquês de Marialva, embaixador extraordinário de Portugal na França e estribeiro-mor do Reino-uma espécie de diplomata português especializado nas questões internacionais -, contando com seu "prestígio e talento", teria se encarregado de contratar, por ordem expressa de seu governo, diversos artistas reconhecidos em seu meio que, em conseqüência da queda do Império de Napoleão preocupados com as represálias, andavam desejosos de emigrar.

Mas essa é a versão oficial da "missão", que narra tudo reservando para a corte a proeminência e o controle sobre os atos. $\mathrm{O}$ suposto é que essa teria sido uma intenção exclusivamente portuguesa - mais particularmente do afrancesado conde da Barca-, que "convidara" figuras proeminentes do cenário cultural francês a fim de criar uma escola profissional para a formação não só de artistas, como de trabalhadores industriais, que possibilitassem transformar o Brasil num centro independente e autônomo. Mas é de estranhar o motivo de a corte selecionar justamente artistas franceses e, ainda mais, diretamente ligados a Napoleão e a David - o primo de Debret -, mais conhecido a essas alturas como "o regicida de Luis XVI". Além do mais, havia no mercado pintores italianos, paisagistas holandeses e famosos retratistas ingleses e até mesmo alguns artistas portugueses igualmente à disposição, que, com certeza, trariam menos embaraços políticos do que nossos artistas franceses. Por outro lado, Marialva mal teve tempo de tomar conhecimento das tratativas com os pintores franceses, uma vez que deixou seu cargo na França em 1815, sendo substituído por Francisco José Maria de Brito, o "Chevalier de Brito" (conforme costumava assinar), como encarregado dos negócios de Paris. Por fim, o conde da Barca, até bem perto da chegada dos artistas, estava pouco inteirado de toda a questão, já que a vinda dos franceses não fazia parte das determinações da corte no Brasil.

Partiu dos artistas, pois, toda a iniciativa e a realização do projeto, e o governo por- 
18 Araújo Porto-Alegre, Belas-artes no 47 e 48, Rio de Janeiro, s.e. p. 193.

19 Idem, "Algumas Idéias sobre as Belas-Artes e a Indústria no Brasil", in Guanabara, Rio de Janeiro, 1851, s.e., p. 142.

20 Gonzaga Duque Estrada, AArte Brasileira, Campinas, Mercado das Letras, 1995

21 Oliveira Lima, D. João VI no Brasil, Rio de Janeiro, Topbooks, 2007

22 Araújo Viana, "Das Artes Plásticas no Brasil em Geral e na Cidade do Rio de Janeiro em Particular", in Revista do Instituto Histórico e Geográfico Brasileiro, Rio de Janeiro, tomo 78 (1915), parte II, Rio de Janeiro, 1916, pp. 546-7.

23 Escragnolle Taunay, A Missão Artística de 1816, Rio de laneiro, Ministério da Educação e Cultura, 1956, pp. 1-5. tuguês só apoiou o grupo quando o mesmo chegou ao Brasil. Quem, de fato, acabaria por garantir a viagem dos artistas, pagando pessoalmente pelos gastos de alguns deles, seria o ministro português José Maria de Brito, em Paris, que é quem troca cartas com Lebreton a respeito da possível vinda de profissionais neoclássicos. Nesse caso, e visto sob esse ângulo, a iniciativa teria sido toda de Joaquim Lebreton - o secretário perpétuo do Instituto de França - e não do Estado português.

Essa anedota histórica muita polêmica iria gerar. Uma das primeiras fontes está nos escritos do próprio Jean-Baptiste Debret, que, no terceiro volume de sua obra Voyage Pittoresque et Historique au Brésil, comenta o caso. O primo de David, que foi o único artista a elaborar um livro sobre sua experiência no Brasil, capricha na idéia de como foram "bondosamente acolhidos", e na certeza de que o projeto era do governo português e, nomeadamente, do conde da Barca. Melhor ser convidado - e por um príncipe - do que passar para a história como aquele que "se convidou".

Araújo Porto-Alegre, o mais conhecido dos discípulos de Debret - professor daAcademia a partir de 1837 -, também sustentou a tese de que diante da queda de Napoleão, do exílio de David e da reação dos Bourbons "ficaram muitos artistas desgostosos em Paris, os quais foram chamados ao Brasil para formarem uma Academia"18. Na revista Guanabara, Porto-Alegre referia-se àquela "formosa colônia artística", expressão que repete com algumas variações em outros textos. Mas o grupo era então definido como uma "colônia", não como "missão"19. Gonzaga Duque, em A Arte Brasileira, de 1888 , acompanha as teses anteriores e usa a expressão "colônia de artistas franceses", e algumas vezes "colônia Lebreton", endossando, assim, a interpretação de Debret, que teria se referido à notre colonie $e^{20}$. Uma outra versão consagrada sobre o tema surgiria com o livro D. João VI no Brasil, de Oliveira Lima, publicado em 1909, que também apostou no projeto premeditado de D. João ${ }^{21}$. Na descrição desenvolvida pelo embaixador, a política da corte surge como absolutamente central e um certo projeto de emancipação é anunciado muito antes de sua efetiva realização ou intenção. Que D. João e seu governo lucrariam com a estada prolongada dos franceses não se discute. $\mathrm{O}$ que está em questão é a premeditação do projeto e a falta de atenção aos interesses e projeções dos próprios franceses.

Em 1915,Araújo Viana profere e publica duas conferências no Instituto Histórico e Geográfico Brasileiro, intituladas “Das Artes Plásticas no Brasil em Geral e na Cidade do Rio de Janeiro em Particular". Vale a pena anotar que, na primeira conferência, o autor refere-se aos pintores como "ilustres artistas franceses". No entanto, nas demais menciona a expressão "missão francesa"; primeiro em letras minúsculas e depois maiúsculas ${ }^{22}$. O fato é que a "colônia francesa" ou a "colônia Lebreton" ganha - e mantém - o nome de "Missão", e em maiúscula, poucos anos antes, com a publicação do extenso estudo de Afonso d'Escragnolle Taunay - "A Missão Artística de 1816" -, na consagrada Revista do Instituto Histórico e Geográfico Brasileiro de 1912. Tal interpretação receberia, então, estatuto de verdade, sobretudo com a publicação do mesmo ensaio em livro, no ano de 1956.

Descendente direto de Nicolas-Antoine Taunay, Afonso introduz a hipótese principal de que, dentre as medidas de D. João, e influenciado por seu ministro D. Antonio de Araújo, estava a criação de uma escola real "para o bem do Brasil". Escragnolle, em nome de reabilitar a imagem de D. João, introduz a idéia da “Missão”. Segundo o historiador, "a colônia americana vivia abandonada, esquecida e ignorada pelo mundo culto" e só contava com pintores e escultores "medíocres". Também a iconografia portuguesa seria caracterizada como "pobre", sendo que a vinda dos pintores franceses tiraria a colônia "da modorra secular" em que se encontrava. Taunay investe pesado na idéia da existência de uma missão e da abertura de "uma nova era"23.

Afonso Taunay, ao mesmo tempo em que introduz novos dados e documentos, retoma e aprofunda argumentos anteriores, conferindo total intencionalidade ao projeto. 
Recuperar a imagem de D. João significava, nesse caso, garantir a ele a autoria da idéia. Como veremos, se o projeto pareceu agradar a alguns elementos da corte, nem por isso o governo terialhe conferido um caráter oficial. Tanto que a ambiguiidade na recepção do grupo - sua importância artística ou industrial - ficaria escancarada mesmo na época da chegada e da instalação dos franceses e nunca foi exatamente esclarecida. Por fim, em 1916, o próprio IHGB promoveria uma série de comemorações por conta do centenário da chegada do grupo de artistas que, nesse contexto, já é chamado, tão-somente, de “Missão Francesa”. Juntava-se, assim, o prestígio da família Taunay com a tradição de uma instituição, e a "colônia de artistas" passava a ser entendida como uma "missão". Interessante é que, como mostra Guilherme Gomes, a palavra "missão" pressupõe uma idéia de obrigação, compromisso e dever por parte dos "missionários", tarefas essas que não se aplicavam a esse contexto preciso. O termo tem origem no mesmo campo semântico de "missa", derivado de minere (“enviar”), que indica, como diz o antropólogo, um mandato, uma incumbência ${ }^{24}$. Não obstante, Afonso Taunay trataria de conferir esse caráter abnegado e até sacrifical aos missionários.

Mais do que julgar, vale a pena entender a importância do debate que se efetiva a partir do centenário da vinda dos artistas franceses. Ao que tudo indica, não estamos diante das tertúlias que por vezes a historiografia trava, mas frente à defesa de uma certa memória, que dependia da certeza do caráter oficial e dadivoso dos nossos - agora - "missionários". Como mostram os termos - que surgem num crescendo -, os artistas se transformavam quase que em religiosos da arte, portadores de uma nova "fé", que, nesse caso, implicava trazer a própria civilização.

Em 1916, no artigo chamado "Um Século de Pintura", Laudelino Freire recuperaria a mesma história, desconfiando, porém, do caráter oficial da missão. Usando as fontes legadas por Henrique José da Silva, um adversário ferrenho dos artistas franceses, argumenta:
"Somos inclinados a admitir que, no tocante à cultura de belas-artes ao invés de dever a vinda dos professores franceses a qualquer ato de resolução do rei, deve-a o país à circunstância de um mero movimento de fonte própria sugerido pelos intuitos a que se entregaram aqueles artistas de buscar em aventuras ultramarinas o remédio ou lenitivo aos seus males" 25 .

Laudelino Freire havia se baseado em artigo publicado no Diário Fluminense, de 12 de janeiro de 1828, que sustentava, já naquela ocasião, que os artistas estrangeiros teriam aqui aportado sem ser convidados. O texto, evidentemente redigido por partidários de Henrique José, refuta a idéia de que existiria um interesse real na vinda do grupo. Questionando tudo o que havia sido escrito até então, escreve Freire: "Não se inspiraram em boa fonte, nem se estribam em documentos e fatos aqueles que primeiro afirmaram, e os que repetiram - que D. João mandara contratar e vir da Europa uma missão de professores para aqui instituir o ensino das belas-artes".

O estudioso Morales de Los Rios, em trabalho de 1942, voltaria à mesma interpretação hegemônica, procurando corrigir o que lhe parecia ser "uma espécie de má fé"26. Versões viram logo fatos acabados quando passam de mão em mão; e assim Morales de Los Rios basicamente recuperava os argumentos de Afonso Taunay, mostrando como, no bojo das inovações trazidas pela corte, "faltava uma escola ou instituto teórico-prático de aprendizagem artística e técnico-profissional ${ }^{27}$. A cada nova versão a Missão ganhava não só realidade como crescia como empreendimento, se não messiânico ao menos religioso. O próprio Afonso Taunay, na sua edição de 1956 , trataria de acender novamente o debate, opondo-se frontalmente a Laudelino Freire e mostrando como o tema era da maior importância para o entendimento não só da Missão como da própria história do Brasil ${ }^{28}$.

Mas o tema seria novamente retomado sob outro viés. Mário Barata coletou referências documentais presentes em arquivos brasileiros, e em 1959 publicou na Revista
24 Guilherme Simões Gomes Júnior Sobre Quadros elivros, Rotina Acadêmicas - Paris e Rio de Janeiro, Século XIX, São Paulo, PUC, 2005

25 Laudelino Freire, Um Século de Pintura, tomo 1, p. 3. Citado por Mario Pedrosa Acadêmicose Modernos, São Paulo, Edusp, 2004 , p. 60. No próximo item trataremos especialmente de Henrique José e da disputa travada por ele e seu grupo pela liderança da Escola de Belas-Artes.

26 Morales de Los Rios, O Ensino Artístico, Rio de Janeiro, Imprensa Nacional, 1942

27 ldem, ibidem, p. 12

28 Afonso Taunay, op. cit., p. 21. 
29 Mário Barata, "Lebreton et I'Organisation d'Une DoubleEcole des Beaux-Arts et des Arts Métiers au Brésil en 1816. A Propos de la Mission Artistique Française de 1816", in Congrès International d'Histoire de l'Art, Paris, Unesco, 1959, pp. $283-$ 307.

30 Donato Mello Junior, "Nicolau Antonio Taunay, Precursor da Missão, Artística Francesa de 1816. Duas Cartas Suas Inéditas Colocam-no na Origem Remoła da Missão", in Revista do Instituto Histórico e Geográfico Brasileiro, n. 327 Rio de Janeiro, abril/junho de 1980. Para um excelente apanhado do tema ver o texto de Elaine Dias, "Correspondências entre Joachim Le Breton e a Corte Portuguesa na Europa. O Nascimento da Missão Artística de 1816", in Anais do Museu Paulista. História e Cultura Material, vol. 14, n. 2, São Paulo, Universidade de São Paulo, jul.dez./2006.

31 Ver também tese de Alberto $\mathrm{C}$ piniuk, l'Origine de l'Académie des Beaux-Arts de Rio deJaneiro, Paris, thèse presentée pour l'obtension du grade de Docteur en Philosophie et Lettres, Université libre de Bruxelles, 1989-90. Nesse trabalho, 0 autor demonstra como o grupo evidentemente havia se convidado e não recebido uma oferta oficial. Elaine Dias, em sua tese Félix-Emile Taunay: Cidade e Natureza no Brasil (Campinas Unicamp, 2005), defende interpretação semehante.

32 Claudine Lebrun Jouve, Nicolas-Antoine Taunay, Arthena 2002, p. 399.

33 Ver Elaine Dias, Félix-Emile Taunay: Cidade e Natureza no Brasil, pp. 29-30. A autora reproduz, em sua importante pesquisa, cópias dos ofícios da corte portuguesa e as correspondências trocadas entre Francisco José Maria Brito e Joaquim Lebreton. Arquivo Nacional da Torre do Tombo (ANTT). Ofício n. 21, 3 de outubro de 1815, ANTT. do Patrimônio Histórico e Artístico Nacional o original dos escritos de Lebreton. A partir desses ofícios foi possível começar a desconfiar dessa história, tão bem arrumada, e tentar entender quais eram as motivações dos próprios artistas, que não ficaram alheios ao imaginário que reinava acerca do Brasil. Como se dizia, a colônia Brasil andava na moda, naFrança, eboaparte do incentivo veio justamente desse universo de fontes culturais, lentamente acumuladas ${ }^{29}$. Mário Pedrosa, em 1957, seria o primeiro a desconfiar de forma direta, e documentada, da iniciativa exclusiva de D. João: "Há hoje uma lenda para o que se convencionou designar de 'missão francesa', ou aquele punhado de cidadãos da França napoleônica que embarcaram para o Brasil em janeiro de 1816, depois de tratos com o encarregado de negócios de Portugal em Paris, e trazendo cartas de recomendação do mesmo diplomata para ministros do rei”. Trata-se, assim, de retomar a pátina do tempo e da lenda, e de repensar as diferentes partes interessadas nesse jogo. Foi em 1980 que Donato Mello Junior descobriu duas cartas escritas por Nicolas Taunay, que, de alguma maneira, contradizem afirmações de seu bisneto. Nessas missivas o artista, com 60 anos feitos, oferece, ao príncipe e à princesa de Portugal, seus serviços como professor das princesas e dos príncipes D. Miguel e D. Pedro, e também na condição de conservador das coleções de arte da corte real $^{30}$. Naquela que recebe Carlota Joaquina, Taunay inclusive vangloria-se de suas relações pessoais com a realeza portuguesa e pede para ser contratado como pintor da família real; cargo que - apesar de muito estimado na França-parecia não existir, oficialmente, em Portugal e muito menos no Brasil.

Assim, se a iniciativa do convite não partiu do benfeitor real, nem muito menos das idéias iluministas do conde da Barca, quem sabe tenhamos que nos voltar para a boa e velha égide das relações pessoais: talvez a própria "missão francesa" tenha se convidado para a festa da qual pretendia participar $^{31}$.

Ao que tudo indica, o projeto teria sido mesmo sugerido à corte portuguesa em Paris, no ano de 1815 - portanto, imediatamente após o restabelecimento das relações diplomáticas -, pelo então secretário perpétuo da Quarta Classe de Belas-Artes do Institut de France: Joaquim Lebreton. Até mesmo em Paris a partida do grupo era observada com curiosidade, sem que se desse "nome aos bois". Um jornal parisiense publicava a seguinte nota: "Há quatro dias que o $\mathrm{Sr}$. Lebreton, secretário da 4ㄹ classe do Instituto partiu de Paris com um armador americano, para ir ao Havre, onde já estão todas as pessoas que compõem a caravana destinada ao Brasil [...]. Eles se propõem, chegando ao Rio de Janeiro, a construir um panorama representando a cidade e Roma" ${ }^{32}$. Não se sabia o que tal grupo faria no Brasil, e que tipo de panorama pretendiam construir. Além do mais, por que associar o Brasil a Roma é também tarefa para pensar e imaginar. " $\mathrm{Ca}$ ravana" é o título indicado como a sugerir que esse aglomerado de artistas tinha algo de errante e de nômade.

Por outro lado, alguns documentos conservados no Arquivo da Torre do Tombo, em Lisboa, iluminam a cena a partir de mais outra fresta, evidenciando a liderança de Lebreton na criação da idéia e na formação do grupo ${ }^{33}$. Em uma das missivas, Lebreton menciona a existência de um movimento imigratório de franceses, receosos com os novos destinos políticos da nação - rumo aos Estados Unidos, ao Novo Reino dos Países Baixos e em direção à Alemanha-e afirma a importância de desviar esse fluxo também para o Brasil. O fato é que a primeira tentativa de negociação intentada por Lebreton é imediatamente posterior a Waterloo, e se deu quando, na França, ocorreu um movimento conhecido como "Terror Branco", quando bonapartistas foram massacrados em Marselha, em Nîmes, Avignon e Toulose. Era a época da desforra: políticos foram desligados, dezenove generais foram condenados à morte, e os convencionais regicidas que aderiram aos "Cem Dias" seriam banidos enquanto se impunha a "lei da proscrição". No próprio instituto, as reviravoltas da política ficavam evidentes: além de David, vinte acadêmicos foram excluídos, entre os quais Sieyès, Monge e Lakanal, com quem Lebreton colaborara na época da convenção. 
Com esse tipo de ambiente, era de esperar que bonapartistas tradicionais, como Lebreton, os Taunays, os Debrets e os Grandjeans de Montigny, que até então se filiavam às atividades artísticas da família Bonaparte, pensassem em partir. Por isso também, Lebreton endereça uma série de cartas ao representante português em Paris, todas com a intenção de garantir a vinda de um grupo de especialistas franceses que auxiliariam nas artes e nas indústrias locais. Em seu primeiro ofício, ainda endereçado a Marialva, Lebreton ressalta as recentes dificuldades encontradas para a emigração em países americanos de possessão espanhola. O secretário parecia conhecer bem a realidade, e como os perseguidos políticos preferiam fugir para os Países Baixos e para os Estados Unidos, assim como reconhecia a necessidade de reorientar o movimento em direção a outras regiões do continente americano, as quais, segundo ele, também andavam carentes de desenvolvimento industrial $^{34}$. $\mathrm{O}$ argumento de Lebreton caminha no sentido de explicar como o Brasil era ainda uma colônia pouco procurada por estrangeiros e que, a exemplo do que acontecera no México, seria possível prever a criação de um novo projeto que promovesse a indústria e as artes no Brasil ${ }^{35}$. Iluminista de formação, Lebreton entendia as artes e a indústria como elementos de civilização e pretendia, agora, estender as benesses para outras localidades. Também intenta,

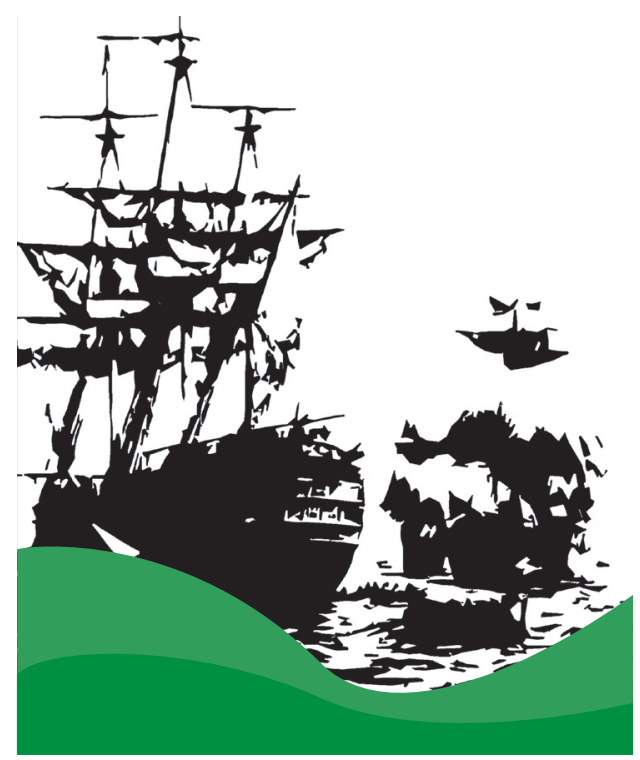

em função da delicada situação política, destacar que não existiria qualquer enlevo revolucionário na iniciativa: “Uma vez acertada essa exclusão, eu gostaria de dirigir ao Brasil os talentos práticos que favorecerão a indústria. Esta categoria de homens é a mais fácil de governar; ela se acha onde quer que esteja e prospera [...]".

Como se pode notar, a propaganda de Lebreton centrava-se na idéia de organizar um grupo "prático e útil”, que trabalhasse na indústria e fosse facilmente governado; dito de outro modo, que não causasse problemas. É fácil notar como Lebreton destaca mais a importância da indústria do que das artes:

"É preciso no Brasil um aumento da indústria, porque os países que o cercam as introduzem todos os dias [...]. É o acaso que, de alguma forma, dirige os homens através do mundo. Não é nem a sabedoria dos governos que garante esse acaso; acontece, como nos Estados Unidos, que pouco ou mal se faz. O Brasil não é invadido por atos políticos ou religiosos: o governo tem o poder de estabelecer um bom sistema de colonização".

Bem informado, Lebreton menciona o caso dos Estados Unidos, como contraposto ao nosso caso, e recupera algumas representações já nesse momento recorrentes: o Brasil era um país promissor, novato para a indústria e sem problemas políticos ou religiosos. Aí estava a velha tópica da terra do mel e sem males, refeita no contexto da Restauração. Menciona também, no mesmo documento, que a política empreendida pelo duque de Richelieu na Rússia poderia ser aplicada no Brasil: o que significava multiplicar a cultura francesa. A situação na França parecia de um lado complicada, e de outro a exportação de especialistas era alardeada como uma espécie de "capacidade francesa" 36 .

Por sinal, não se pode esquecer que essa era uma época em que a "racionalidade" e "as boas maneiras francesas" passavam a ser objeto de consumo. Por exemplo, dispor de domésticas francesas representava uma marca de luxo e distinção. Esse tipo de traba-
34 Ver Elaine Dias, La Circulation des Ouvres d'Art, Paris, Presses Universitaires de Rennes, s.d., p. 268

35 "Ofício n-21, 3 de Outubro de 1815". ANTT. Ver: Elaine Dias, Félix-Emile Taunay: Cidade e Natureza no Brasil, op. cit., p. 28, e "Correspondências entre Joachim Le Breton e a Corte Portuguesa na Europa. $O$ Nascimento da Missão Artística de 1816", op. cit.

36 "Ofício no 21, 3 de Outubro de 1815", ANTT. 
lho era, inclusive, bastante significativo em termos de volume - documentos de época relacionam um total de 150 mil emigra$\operatorname{dos}^{37}$. Também o culto à razão, terminada a Revolução, parecia continuar atrelado à imagem positiva desse país, assim como o mundo se tornava uma espécie de província cultural francesa. Da mesma maneira, se a arte francesa estava no centro do mundo e acima das modas provinciais, já a pintura neoclássica vigente durante o império napoleônico (nomeadamente a pintura de história) serviria como uma espécie de epígrafe para todo e qualquer ensino nas novas academias que então se formavam.

Mas voltemos ao texto, que continua garantindo as vantagens da "aquisição": tudo fácil e sem problemas. É interessante notar que só após ter discorrido sobre as vantagens econômicas e industriais que adviriam da vinda de um grupo de franceses é que Lebreton menciona que a instituição não seria "suntuosa" como a escola mexicana - descrita, como vimos, por Alexandre von Humboldt. Por sinal, Lebreton explica ao cavaleiro Brito como já teria à sua disposição um pintor, um escultor, um arquiteto e um bom gravador. Menciona ainda outros profissionais, como um cirurgião da Armada, o diretor dos jardins de Versalhes, e "um hábil construtor vindo da Espanha": François Ovide, que já estava de partida para o Peru e depois rumaria em direção ao México. No entanto, de todos os nomes mencionados, apenas Ovide e os irmãos Taunay viriam efetivamente ao Brasil ${ }^{38}$.

É só em 9 de outubro de 1815 que o cavaleiro Brito e o marquês de Aguiar escrevem à corte, e transmitem ao príncipe regente a intenção de Lebreton:

37 Georges lefebvre, La Révolution Française, Paris, PUF, 1988 vol. 2, pp. 133-4.

38 Elaine Dias, Félix:Emile Taunay: Cidade e Natureza no Brasil, op. cit., pp. 29-30

39 "Ofício no 21, 3 de Outubro de 1815", ANTT, in Elaine Dias, op. cit., pp. 30-1.

40 "Ofício, no 30, 9 de Dezembro de 1815", ANTT, in Elaine Dias, op. cit., pp. 31-2.
Evidentemente, e mesmo sem ter a carta de resposta de Brito a Lebreton, nota-se como os procedimentos andaram rápido. Em seis dias o ministro já elabora uma proposta ao soberano, sem destacar que os artistas foragidos eram, de alguma maneira (ou ao menos alguns deles), vinculados ao ex-governo de Napoleão. Na sua carta, Brito menciona o talento do gravador Charles Simon Pradier e do arquiteto Grandjean de Montigny, mas deixa claro sua preferência pelo agricultor Lelieur. O ministro se oferece até mesmo para pagar a viagem de Lelieur e de Ovide, caso o negociante português José Alexandre Carneiro Leão não arcasse com as passagens. Com certeza Brito estava mais interessado na indústria do que nas artes, e nunca escondeu suas preferências. Já Lebreton confiava que os comerciantes brasileiros ajudariam no financiamento do grupo, a exemplo do que ocorrera no México. E o imaginário vencia a própria realidade. O suposto do secretário é que o que valia para o México servia para o Brasil. A América era uma só América: conhecida ou sonhada.

Mas em dezembro, em nova missiva, Brito desaponta Lebreton, lembrando que não existiria qualquer instrução da corte no sentido de garantir a vinda dos franceses, e muito menos fundos para pagar a passagem desses artistas:

"Reiterando-lhe, senhor, que me faltava informação a esse respeito, eu não poderia nem lhe dar alguma promessa para o futuro, nem assumir um compromisso que poderia prejulgar as intenções de meu governo, apesar de conhecer os seus princípios e sua política esclarecida, para não duvidar que adotem todos os meios de fazer progredir a civilização e a prosperidade de seus vastos territórios, uma vez que os meios trazidos do estrangeiro lhe forneçam uma garantia de segurança, e de pleno emprego em troca dos favores que serão acordados" ${ }^{40}$.

Assim, se Brito não descarta a importância do projeto, e o vincula à política esclarecida de D. João e a seu apego à civilização, não garante qualquer aporte. 
Por outro lado, caso os profissionais chegassem ao Brasil, o governo concordaria em apoiar a estada durante os primeiros anos. A repetição era, porém, sempre a mesma: essa não era nem uma promessa, nem um objetivo do príncipe regente. Além do mais, o ministro português propõe a Lebreton a inclusão de alguns literatos franceses, caso o projeto viesse a vingar. $\mathrm{E}$ a resposta de Lebreton não deixa dúvidas: “Os sábios de literatura francesa são elementos de difícil amálgama e talvez de uma utilidade bastante limitada no estrangeiro, e, portanto, não propus nada nesse sentido [...]. Escolhendo homens trabalhadores e honestos, donos de uma profissão prática, eu acreditei servir à sua e à minha pátria e os dois príncipes que as governam"41. Lebreton é claro em seus propósitos e nos ajuda a entender de que maneira, nesse contexto, os franceses se entendiam únicos e as belas-artes pareciam estar mais afinadas com o Estado e com "a Pátria”. Elas seriam "profissões práticas”, como propaganda da nação.

Depois dessa troca de correspondências, Brito passa a apostar, de verdade, no projeto de Lebreton e paga pessoalmente as despesas da viagem de Grandjean de Montigny e de Pradier, junto com suas respectivas famílias. Também concorda em financiar os gastos de Lebreton e de Ovide, assim como os custos do envio de algumas máquinas - mais especificamente três moinhos - ao Brasil. Ao que tudo indica, se o príncipe não financiou a vinda dos artistas, alguns representantes portugueses residentes na França o fizeram. O "Chevalier de Brito" adiantaria a importância de 10 mil francos em ouro para que a viagem se realizasse logo, evitando assim "as delongas naturais em negociações de tal natureza, mormente considerando a distância entre Paris e Rio de Janeiro"42. Com tal soma, Lebreton deveria pagar não só suas despesas, como as passagens de Montigny, de Pradier, de Auguste Taunay e de François Ovide. De toda maneira, Lebreton parece acreditar que no Brasil existiria uma grande possibilidade de desenvolvimento dos "ofícios", assim como apostava que, dadas as dificuldades políticas e sociais por que passava o continente europeu, muitos artesãos ou oficiais especializados poderiam ser aproveitados ${ }^{43}$

Lebreton pretendia, originalmente, conseguir verba para o grupo todo, mas, não sendo possível, passou recibos de 5 mil francos, os quais, segundo ofício de 8 de abril de 1816, seriam "reembolsados imediatamente" pelo governo português ${ }^{44}$. Jamais foi encontrada a correspondência mencionando a devolução do dinheiro. De toda forma, como já foi mostrado, em 9 de outubro de 1815 o cavaleiro Brito e o marquês de Aguiar escrevem mais uma vez à corte e transmitem a D. João alguns aspectos da troca de correspondência com Lebreton.

O fato é que a "missão" não era oficial, nem no Brasil nem na França. Afinal, não foram encontrados documentos nos arquivos da Quarta Classe de Belas-Artes do Institut de France, no período em que Lebreton fora secretário perpétuo; apenas a ata de dezembro de 1815 , em que Lebreton lê a carta de afastamento de Taunay e, na seqüência, engata o seu próprio pedido de licença. A justificativa de Taunay fala por si só: "Vou a um país cuja natureza muito me inspirará". Era a natureza do Brasil que, mais uma vez, fazia o papel de texto e pretexto para a viagem.

A organização do grupo deve ser entendida como uma iniciativa pessoal do secretário, o qual, em 1815, passado o episódio em que discursara contra os ingleses no que se refere à devolução das peças retiradas dos países conquistados no período de Bonaparte, encontrava-se num momento complicado e com seu emprego em risco $^{45}$. Além do mais, Lebreton era conhecido nesse mundo das artes e tinha capital político para juntar rapidamente um grupo de artistas em situação parecida com a sua.

Francisco José Maria Brito foi, porém, precavido. Como arcara com parte das despesas, toma também o cuidado de enviar cartas ao "ministro d'Araujo", apresentando o grupo de artistas e o projeto que pretendiam desenvolver no Brasil. Mesmo assim, e já no momento da partida dos franceses, alerta, uma vez mais, a Lebreton:
41 "Ofício no 30 Datado de 20 de Dezembro de 1815", ANTT, in Elaine Dias, op. cit., p. 32 .

42 Gean Maria Bittencourt, A Missão Artística Francesa de 1816, Museu das Armas, 1967, p. 6.

43 In Elaine Dias "Correspondências entre Joachim Le Breton e a Corte Portuguesa na Europa. $O$ Nascimento da Missão Arística de 1816", op. cit., p. 306.

44 Gean Maria Bittencourt, op. cit, p. 7.

45 Ver Elaine Dias, "Correspondências entre Joachim Le Breton e a Corte Portuguesa na Europa. $O$ Nascimento da Missão Artística de 1816", op. cit., p. 311. 
“Assim, senhor, nesse empreendimento que é todo seu, espero que reconheça que não lhe fiz nenhuma promessa, nem me comprometi por conta do meu governo. Compete somente a ele conceder-lhe uma acolhida hospitaleira e que os talentos e a indústria sempre encontraram entre nós, na sombra das leis sábias e paternais que tantos estrangeiros devem abençoar por gratidão"46.

Além de registrar que o projeto era “todo" de Lebreton, Brito não faz qualquer promessa, assim como reitera não existir engajamento oficial. Há um verdadeiro silêncio por parte da Coroa no Brasil, e ela só entra nessa história quando a "colônia francesa" efetivamente chega ao Brasil. Por sua vez, na carta final que Lebreton envia a Brito, em 20 de dezembro de 1815, já com tudo acertado, o secretário lembraria que só pretendia ser útil nesse "país respeitado e promissor". A idéia de uma terra de promissão está outra vez presente, mostrando como o imaginário francês era mesmo um bom ticket de viagem.

Hora de juntar as cartas: artistas desempregados ou em vias de ser; uma moda francesa nas artes; uma monarquia européia estacionada nas Américas; uma colônia até então fechada aos estrangeiros - sobretudo franceses - e com imensas possibilidades de comércio, mercado e artes, e um príncipe carente de representação oficial. É preciso, pois, combinar isso tudo e ainda adicionar mais dois elementos: o papel do Brasil no imaginário francês e o fato de nossos viajantes saberem que a língua culta da realeza e de uma parte da elite da corte era justamente o francês. Com todos esses argumentos reunidos, talvez o mais correto seja pensar que, juntando a fome com a vontade de comer, os viajantes decidiram partir: alguns financiados, outros não. Por seu lado, a Coroa só daria seu apoio com o fato consumado. Aí sim pagaria pela estada dos artistas em território americano. Convidados ou não, o fato é que a partir dessa troca de correspondências pode-se atestar que existiram relações entre a oficialidade da diplomacia portuguesa e os artistas franceses e que os mesmos chegaram protegidos. Pode-se perceber mais: como o Brasil continuava fazendo parte dos mapas imaginosos dos franceses.

Foi apenas no Rio de Janeiro, em 1816, e contando finalmente com o apoio de D. João, que o conde da Barca deu início aos primeiros preparativos para a recepção do grupo de artistas franceses. D. Araújo apoiaria, então, efetivamente o projeto de Lebreton e animaria D. João com a idéia da criação de uma "escola ou instituto prático de aprendizagem e técnico-profissional", que viria a complementar a série de "excelentes iniciativas", que "teriam sido favoráveis a nosso país" 47 . Projeções irmanadas faziam agora com que o projeto desse certo.

\section{FECHANDO E ABRINDO ESSA HISTÓRIA: COINCIDÊNCIAS E MUITA IMAGINAÇ̃̃O}

Quando a "colônia Lebreton” aportou no Brasil a corte já estava resolvida a levar em frente a idéia de contratar esses artistas vacantes no mercado. Não se pode esquecer também que nessa época a França parecia simbolizar a civilização e a cultura, e os pintores vindos daquela nação valiam, sem dúvida, mais no mercado das artes. Marialva, que, como vimos, fora até 1815 ministro na França, teria pedido a intermediação de Humboldt, nesse contexto, um dos homens mais conhecidos no ambiente das instituições científicas. Por outro lado, conforme explica Debret, Humboldt possuía influência também junto à corte portuguesa e pode ter sido dele a idéia de indicar o nome de Joaquim Lebreton a Marialva como possível articulador de um projeto no Brasil. Além do mais, sabia, também, que Lebreton havia sido subscritor da École Royale du Dessin, de Bachelier, em Paris, desde 1788, e que presidia o Conselho de Administração desde 1881, tendo, portanto, experiência no desenvolvimento de 
projetos artísticos no âmbito institucional. É preciso lembrar, ainda, que nessa época Lebreton, continuava com sua função de administrador das Obras de Arte no Museu do Louvre (cargo que ocupava desde 1798), e se transformara em colaborador de Vivant Denon na organização das coleções em $1802^{48}$. Parecia ser, portanto, o homem certo para o lugar certo. O papel de Humboldt seria, assim, destacado em muitos aspectos: partiria dele a indicação do nome de Lebreton e sua visão da América influenciaria o líder do grupo, mas também os demais participantes.

Toda a operação seria realizada às pressas; tão depressa como o mundo mudava naquele contexto. Fernando VII voltara a reinar na Espanha - revogando as medidas de Cádiz e do governo napoleônico - e a América espanhola entrava na fase final das lutas pela independência. Em meio a esse ambiente convulsionado, o Rio de Janeiro parecia uma espécie de ilha de sossego, ainda mais garantida pela presença da monarquia portuguesa. Assim, munida de vários temores, da incerteza política e do ânimo recobrado pelos relatos que prometiam, de fato, um Novo Mundo, partiu a “colônia Lebreton". Por certo, pensavam que conseguiriam dinheiro fácil, junto a uma corte imigrada e de um povo sem educação artística formal. No entanto, o país era distante, desconhecido e só recentemente o príncipe declarara o final da guerra com Napoleão. Além do mais, conheciam muito pouco acerca dessa colônia, descrita apenas nos relatos dos viajantes e compiladores franceses. Provavelmente imaginavam estar chegando numa terra de clima tropical, coberta de matas, papagaios, serpentes e macacos; povoada por índios, negros e mestiços. Mas pensavam, ainda, que a fortuna morava por lá e que a cultura estava para ser semeada.

O fatoé que havia muitas expectativas de parte a parte: a corte entendia a chegada dos artistas franceses como a própria entrada da civilização. Já nossos artistas acreditavam estar aportando em território virgem em dois sentidos, no mundo das artes e da natureza. Mas não se pode apostar na idéia de que formar uma academia, com artistas profissionais, fosse um projeto totalmente novo e original. Exemplos parecidos existiam, e não poucas nações da América espanhola, como o México, começavam a conformar acervos oficiais com o intuito de criar verdadeiras iconografias de Estado.

Foi assim, juntando muitos interesses, cruzando vários imaginários e algumas coincidências, que em 26 de março de 1816 o pequeno barco norte-americano a vela aporta no Brasil. Foram dois meses de translado, e como o navio não podia passar pela barra da Baía da Guanabara, fechada por causa do tráfico marítimo durante a noite, o Calphe teve que jogar suas âncoras ainda no mar. Já nesse momento os passageiros ouviram tiros que eram, na verdade, saudações fúnebres em honra de D. Maria I, que havia acabado de falecer. Tendo diante dos olhos uma paisagem tropical exuberante, aportados em frente ao Pão de Açúcar, e contando com a luz inesperada dos fogos de artifício, projetados por causa das exéquias da rainha, os artistas passaram a noite fazendo uma série de projetos, e sonhando com realizações, que, infelizmente, não chegariam a bom termo.

Os fogos de artifício eram rituais e não indicavam a entrada na guerra, mas entre sustos e muita esperança os franceses imaginavam uma nova pátria para adotar, para sempre ou por período breve. Debret, no seu livro Viagem Pitoresca, descreveu o ambiente: "O ardor natural dos artistas franceses despertava as ilusões gloriosas que deviam conformar nosso primeiro passo rumo a uma terra desconhecida [...]. Será fácil acreditar que foi o sonho universal a embelezar o sono de cada um dos artistas, na sua última noite de viagem" ${ }^{49}$. Cada um com seu sonho, cada um com sua própria imaginação, à espera, ainda no navio, de que algo de muito novo finalmente surgisse.
48 Ver Elaine Dias, "Correspondências entre Joachim Le Breton ea Corte Portuguesa na Europa. O Nascimento da Missão Artística de 1816", op. cit.

49 Jean-Baptist Debret, Viagem Pitoresca e Histórica ao Brasil, 2 vol. São Paulo, Martins/Edusp, 1972, vol. 1, t. II, p. 25 